\title{
Biomass expansion factor and root-to-shoot ratio for Pinus in Brazil
}

Carlos R Sanquetta ${ }^{1 *}$, Ana PD Corte $2^{2^{*}}$ and Fernando da Silva ${ }^{3}$

\begin{abstract}
The Biomass Expansion Factor (BEF) and the Root-to-Shoot Ratio (R) are variables used to quantify carbon stock in forests. They are often considered as constant or species/area specific values in most studies. This study aimed at showing tree size and age dependence upon BEF and $\mathrm{R}$ and proposed equations to improve forest biomass and carbon stock. Data from 70 sample Pinus spp. grown in southern Brazil trees in different diameter classes and ages were used to demonstrate the correlation between BEF and R, and forest inventory data, such as DBH, tree height and age. Total dry biomass, carbon stock and $\mathrm{CO}_{2}$ equivalent were simulated using the IPCC default values of BEF and $\mathrm{R}$, corresponding average calculated from data used in this study, as well as the values estimated by regression equations. The mean values of BEF and $\mathrm{R}$ calculated in this study were 1.47 and 0.17 , respectively. The relationship between $B E F$ and $R$ and the tree measurement variables were inversely related with negative exponential behavior. Simulations indicated that use of fixed values of BEF and R, either IPCC default or current average data, may lead to unreliable estimates of carbon stock inventories and CDM projects. It was concluded that accounting for the variations in $\mathrm{BEF}$ and $\mathrm{R}$ and using regression equations to relate them to $\mathrm{DBH}$, tree height and age, is fundamental in obtaining reliable estimates of forest tree biomass, carbon sink and $\mathrm{CO}_{2}$ equivalent.
\end{abstract}

Keywords: allometry, carbon, regression, CDM, modeling

\section{Background}

CDM (Clean Development Mechanism) enables developing countries to participate in global efforts to reduce greenhouse gases (GHG) concentrations in the atmosphere and to accomplish the Kyoto Protocol commitments. However, few A/R CDM approved methodologies were available until recently and hence a small number of PDDs (Project Design Documents) were submitted to the CDM Executive Board (EB) of the UNFCCC (United Nations Framework Convention on Climate Change). One of the main constraints to proposing an adequate $\mathrm{A} / \mathrm{R}$ methodology and applying it in a PDD is the difficulty in identifying and monitoring the complex biological relationships in a forest plantation as well as obtaining reliable estimates of biomass and carbon stocks. In recent years, several methodologies have

\footnotetext{
* Correspondence: sanquetta@ufpr.br; anapaulacorte@gmail.com 'Department of Forest Science, Federal University of Paraná, Curitiba, PR, Brazil. Av. Prof. Lothário Meissner, 900, Jardim Botânico, Curitiba, Paraná, 80.210-170, Brazil

${ }^{2}$ Forestry Research Foundation of Paraná, Curitiba, PR, Brazil. Av. Prof. Lothário Meissner, 900, Jardim Botânico, Curitiba, Paraná, 80.210-170, Brazil Full list of author information is available at the end of the article
}

been approved by the EB that allow us to obtain stock change estimates for large forest areas, but they are complex and difficult do apply.

There are different approaches to calculating biomass and carbon stocks in forests. These are mostly based on forest inventory information as well as various factors, referred to as biomass factors, or biomass equations, which transform diameter, height or volume data into biomass estimates [1]. The calculations can be obtained by direct and indirect methods [2]. The direct method involves destructive biomass weighing, whereas in the indirect method regression modeling is used to estimate biomass and carbon stocks from more easily-measured tree and stand variables, such as DBH (diameter at breast height), tree height $(\mathrm{H})$ and age. The use of either the direct or indirect methods may provide information to construct a figure of $\mathrm{CO}_{2}$ removal for a $\mathrm{CDM}$ project for the duration of a crediting period.

Estimates of biomass and carbon stocks from bole volume and wood density generally require the application of a biomass expansion factor (BEF) or biomass equations to obtain the aboveground and total biomass
C Biomed Central

() 2011 Sanquetta et al; licensee BioMed Central Ltd. This is an Open Access article distributed under the terms of the Creative Commons Attribution License (http://creativecommons.org/licenses/by/2.0), which permits unrestricted use, distribution, and reproduction in any medium, provided the original work is properly cited. 
[3-5]. Because biomass factors are easier to use than biomass equations they have been preferred. BEF is calculated from the ratio of aboveground biomass and bole biomass (defined by a merchantable measure or a minimum $\mathrm{DBH}$ ). When belowground biomass is considered in the CDM project, root-to-shoot ratio (R) also should be taken into account. Calculation of $\mathrm{R}$ involves simply dividing the root biomass by the corresponding aboveground biomass.

BEF and $\mathrm{R}$ application may also vary from project to project. Single default values are often used, as in Kauppi et al. (1992) [6], Kauppi et al. (1995) [7], Lowe et al. (2000) [8], UN-ECE/FAO (2000) [9], FAO (2001) [10] and IPCC (2006) [11]. However, it is known that these factors may vary depending on the species to be planted, growth phase, and site index [12]. Therefore, calculations of BEF and $\mathrm{R}$ under specific conditions shall be preferred [13-15].

This study deals with the analysis of correlations of $\mathrm{BEF}$ and $\mathrm{R}$ with some typical tree inventory data $(\mathrm{DBH}$, $\mathrm{H}$ and age) and the development of mathematical modeling relating BEF and $\mathrm{R}$ to the more easily obtained tree measurement variables. In this paper a comparison of three different approaches to estimate biomass and carbon stocks is carried out, (i.e. IPCC default values of $\mathrm{BEF}$ and $\mathrm{R}$ [11], average BEF and R from field data and $\mathrm{BEF}$ and $\mathrm{R}$ estimated from regression equations fitted from specific field data).

\section{Results and Discussion Descriptive Statistics}

Table 1 shown below summarizes the descriptive statistics of the variables analyzed in this study. The average value of BEF calculated from the data was 1.47 , meaning that the crowns of the pine species studied here represent on average $32 \%$ of the aboveground biomass and $27 \%$ of the total biomass, however the variability in this factor was remarkable, ranging from 1.09 to 3.74. As stated before, the mean default value of IPCC for pines growing in the tropics and in similar conditions of this study is 1.30 , ranging from 1.2 to 4.0 .

In work by Levy et al. (2010) [16], for three conifer species in Great Britain, the authors found BEF values ranging from 1.04 to 2.32 . In a study of carbon stocks grown in Western Europe, Liski et al. (2002) [17] found a mean BEF of 1.39, while Schroeder et al. (1997) [18] estimated a mean BEF of 1.25 for adult deciduous tree stands in the US. The IPCC (2006) [11] gives various other BEF figures from literature. However, no specific studies on BEF were found for Brazilian pine plantations or under similar conditions.

Regarding $\mathrm{R}$, the mean value found in this study was 0.17 , varying from 0.05 to 0.63 . This means that on average, belowground biomass corresponds to $15 \%$ of the total biomass. The mean default value for pine in the Tropics is $\mathrm{R}=0.32$, according to IPCC, though a range of 0.24 to 0.50 in this ratio has been reported [11]. In the study by Levy et al. (2010) [16], researchers found an average $R$ of 0.36 ; whereas in the study in western Europe by Liski et al. (2002) [17], mean R was 0.16. The IPCC reported other references on the matter, but literature is not available for pine plantations in Brazil.

It is noteworthy to mention that both BEF and $\mathrm{R}$ figures given by the literature are influenced by the methodology used in each case. Some authors adopt the definition of bole as the main tree trunk up to a minimum diameter. A BEF figure from bole of $4 \mathrm{~cm}$ minimum diameter is obviously rather smaller than another calculated from 10 $\mathrm{cm}$ minimum diameter. It is more problematic for broadleaf species that have sympodial growth than for pines with monopodial crown architecture. Similarly, R is affected by the depth and fine root dimension approach utilized. Deep root excavations and fine root dimension imply in greater root-to-shoot ratios given same conditions.

As can be seen later on in this paper, BEF and $\mathrm{R}$ are correlated with $\mathrm{DBH}$, height, and age, but the relationship among them is hardly constant. On the contrary, as the trees grow and advance in age the contribution of foliage and roots to the total biomass diminishes in both Pinus species studied here, though it will be discussed at greater length later in this paper.

\section{Correlation between BEF, R, DBH, $\mathrm{H}$, and Age}

The correlation analysis performed on the biomass expansion factor and the root-to-shoot ratio, tree diameter, height, and age indicated that BEF and $\mathrm{R}$ have significant correlations with the tree measurement variables, as shown in Table 2. All correlation coefficients

Table 1 Descriptive statistics for DBH, H, Age, BEF, and R

\begin{tabular}{|c|c|c|c|c|c|}
\hline Statistics & $\mathrm{DBH}(\mathrm{cm})$ & $H(m)$ & Age (years) & BEF & $\mathbf{R}$ \\
\hline Mean & 20.10 & 15.15 & 11.44 & 1.47 & 0.17 \\
\hline Standard Deviation & 8.78 & 7.65 & 5.95 & 0.47 & 0.11 \\
\hline Minimum & 1.91 & 2.35 & 2 & 1.09 & 0.05 \\
\hline Maximum & 40.27 & 30.30 & 24 & 3.74 & 0.63 \\
\hline Coefficient of Variation (\%) & 43.68 & 50.50 & 52.01 & 31.97 & 64.71 \\
\hline Number of cases & 70 & 70 & 70 & 70 & 70 \\
\hline
\end{tabular}


Table 2 Correlation matrix between BEF, R, DBH, $\mathrm{H}$ and Age variables

\begin{tabular}{cccccc}
\hline Variable & DBH $(\mathbf{c m})$ & $\mathbf{H}(\mathbf{m})$ & Age (years) & BEF & $\mathbf{R}$ \\
\hline $\mathrm{DBH}(\mathrm{cm})$ & 1 & - & - & - & - \\
$\mathrm{H}(\mathrm{m})$ & 0.922 & 1 & - & - & - \\
Age (years) & 0.869 & 0.960 & 1 & - & - \\
BEF & -0.731 & -0.724 & -0.671 & 1 & - \\
$\mathrm{R}$ & -0.679 & -0.728 & -0.707 & 0.528 & 1 \\
\hline
\end{tabular}

were negative for BEF and $R$ versus tree size and age, indicating a decrease in both tree size and age.

The correlation matrix indicates that $\mathrm{DBH}$ is the variable more closely associated with BEF, followed by height and age, respectively, and that all of them have significant correlations. In contrast to the findings of this study, Levy et al. (2010) [16], Brown \& Schroeder (1999) [19] and Lehtonen et al. (2004) [15] found that tree height has the greatest explanatory power in estimating BEF. In this study, the explanatory power of $\mathrm{DBH}$ and height were nearly the same. Therefore, DBH shall be preferred as the explanatory variable because it is easy to measure, less time consuming and higher precision compared to height.

On the other hand, $\mathrm{R}$ was more closely correlated with height, though age and DBH were also significant. $\mathrm{BEF}$ and $\mathrm{R}$ were also correlated with each other in this study, but the correlation coefficient was moderately smaller. The correlation between BEF and R seems reasonable, since trees need more root biomass to support a proportionally large crown.

\section{Modelling BEF and $\mathrm{R}$ from $\mathrm{DBH}, \mathrm{H}$, and Age}

The results showed that biomass expansion factor and root-to-shoot ratio vary considerably with tree size (DBH and height) and age. The relationships are shown graphically in Figures 1, 2 and 3. In evidence are the

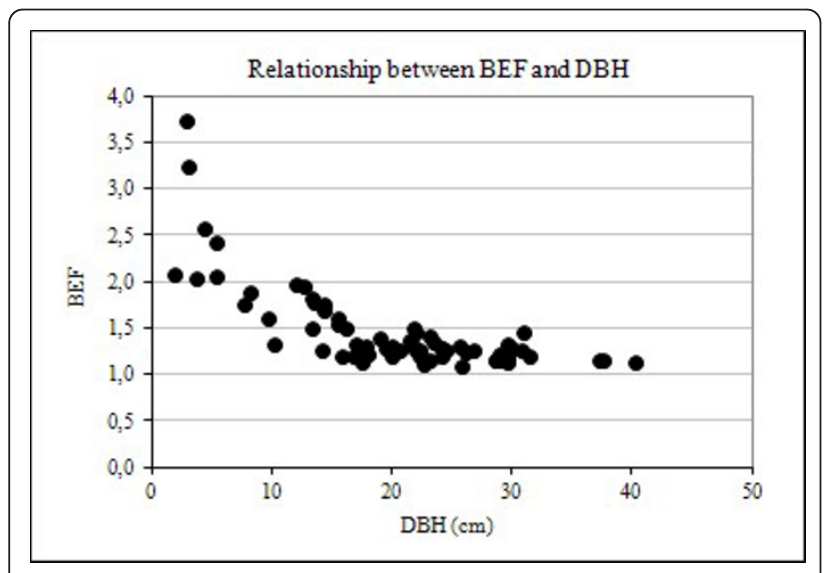

Figure 1 Relationship between BEF and DBH

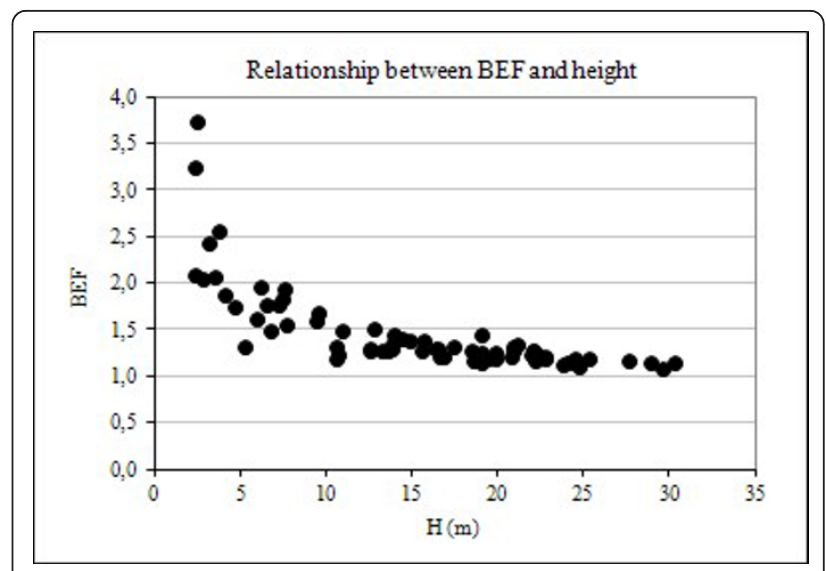

Figure 2 Relationship between BEF and height

relationships between $\mathrm{BEF}$ and $\mathrm{R}$ with $\mathrm{DBH}$, height, and age have a well-defined trend, following an negative exponential curve and that BEF and R decrease as $\mathrm{DBH}$, height, and age increase. Thus, larger and older trees have proportionally less foliage and root biomass as compared to smaller and younger ones. A relative decreasing trend in crown (foliage + branches) and root biomass across a range of tree ages have been reported elsewhere, as in Kauppi et al. (1995) [7], Lehtonen et al. (2004) [15], Brown (2002) [20] and Fukuda et al. (2003) [21].

This trend may be explained by the physiological maturation of trees [22], which require greater photosynthetic biomass to promote faster growth in the earlier phases of this process and resource-use efficiencies of individual trees $[23,24]$, as well as competition with neighbors and canopy closure $[12,25,26]$, which causes shading of the tree crown and limitation of root expansion, and natural pruning [27]. However, a decrease in BEF and $R$ with tree size and age tends to not take

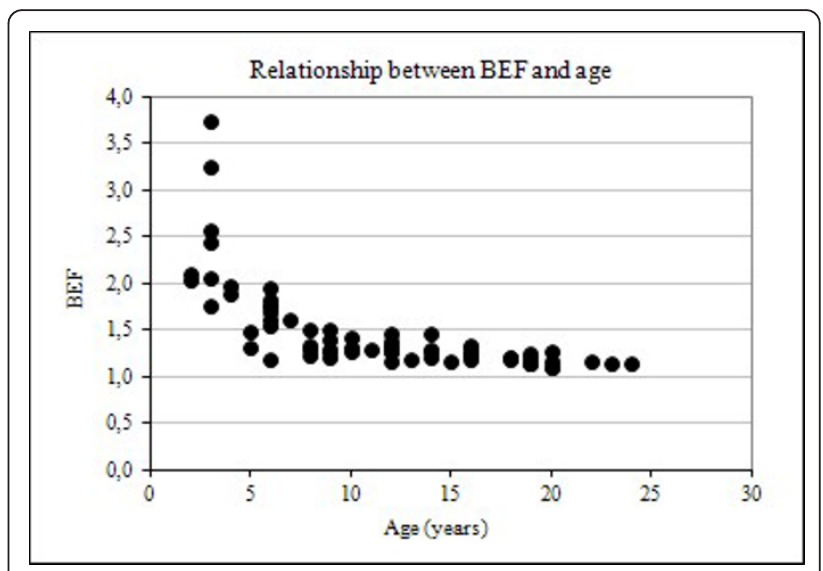

Figure 3 Relationship between BEF and age 
place after a given size and age, suggesting an asymptotic behavior due to stabilization of growth rate and tree maturation.

However, there was noticed heterogeneity of variance in BEF and $\mathrm{R}$ along tree size and age axes. This may be explained by the so-called Jensen's inequality, which describes how variance depresses the response variable in decelerating functions and elevates the response variable in accelerating functions [28,29]. The authors argued that Jensen's inequality provides a fundamental tool for understanding and predicting consequences of variance some direct effects of environmental variance in biological systems.

On the other hand, Magnani et al. (2000) [30] tried to explain the reduction of growth and biomass allocation with ageing from a physiological and hydraulic point of view. It has been shown that younger plants grow taller more quickly. Hence, they need proportionally more photosynthetic biomass than older ones. Some authors consider respiration is a key factor for limitation of foliage growth with ageing (Kira \& Shidei, 1967; Barnes et al. 1998) [31,32]. However, Ryan et al. (2004, 2006) $[33,34]$ rejected the traditional hypothesis that increased respiration of woody tissues forces a decline in aboveground net primary productivity by conducting an experimental test of causes of forest growth with stand age for Eucalyptus. According to the authors the decline was primarily caused by a decline in canopy carbon gain and secondarily by a shift in the annual partitioning of gross primary productivity to belowground allocation and foliage respiration.

Figure 4, 5 and 6 also suggests that $\mathrm{R}$ data dispersion is more pronounced in comparison to $\mathrm{BEF}$, when these factors are plotted against $\mathrm{DBH}$, height, and age, implying that forest inventory variables are more strongly correlated with BEF than with $R$, as seen later in this paper. Another feature of the graphs of BEF and $R$ against

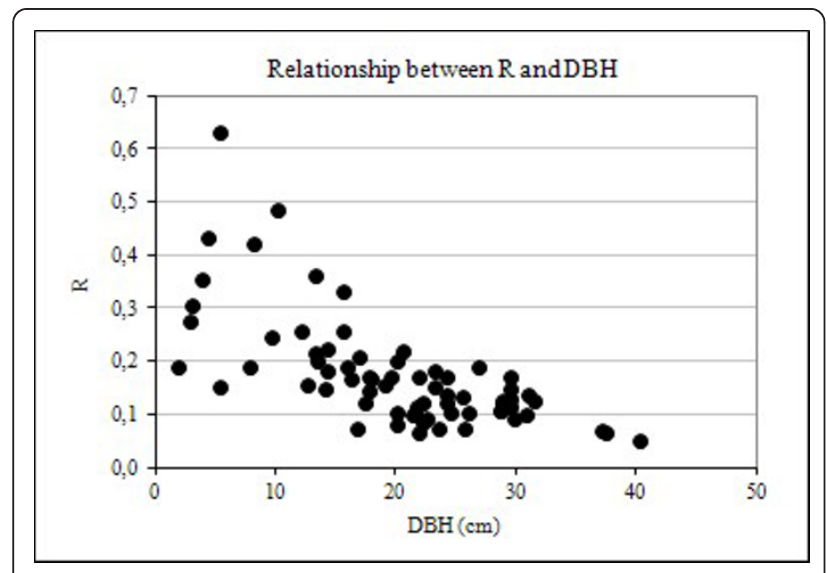

Figure 4 Relationship between $\mathrm{R}$ and $\mathrm{DBH}$

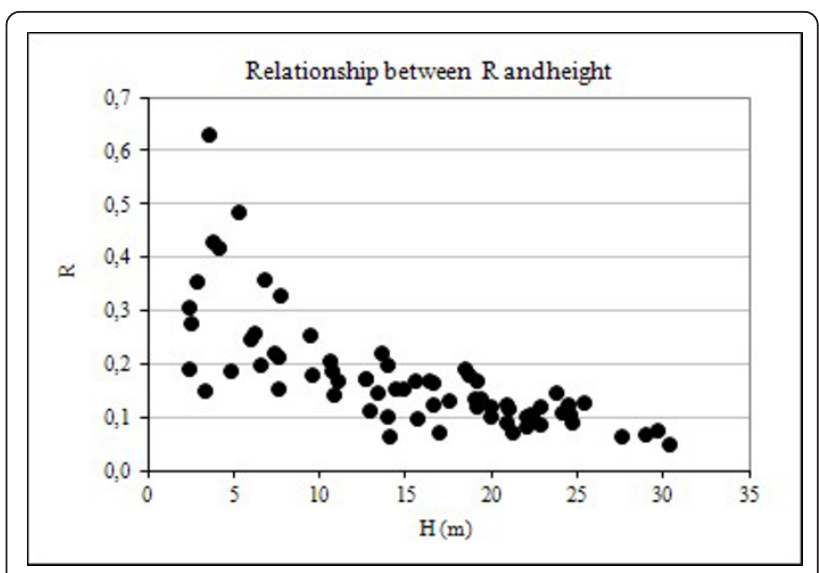

Figure 5 Relationship between $\mathrm{R}$ and height

$\mathrm{DBH}, \mathrm{H}$, and Age, is the greater dispersion for smaller and younger trees.

Similar results were also reported by Lehtonen et al. (2004) [15]. Soares \& Tomé (2004) [35] found analogous trends and concluded from their study on effectiveness of biomass expansion factors that estimates of total stand biomass (aboveground and root biomass) should be derived from allometric equations and if an expansion factor must used then age-dependent BEFs are recommended. They also stated that the use of a constant BEF should be avoided because it yields inaccurate estimates.

Table 3 shows fitting statistics for the 12 models tested to estimate BEF and $\mathrm{R}$ from $\mathrm{DBH}, \mathrm{H}$, and Age. Equations for BEF, in general, resulted in better fit as compared to those for estimating $\mathrm{R}$.

The coefficient of determination for the 12 equations tested to estimate BEF ranged from 0.44 to 0.78 , whereas for $\mathrm{R}$ stayed between 0.35 and 0.59 . The standard error in the estimate for BEF equations ranged from 15.60 to

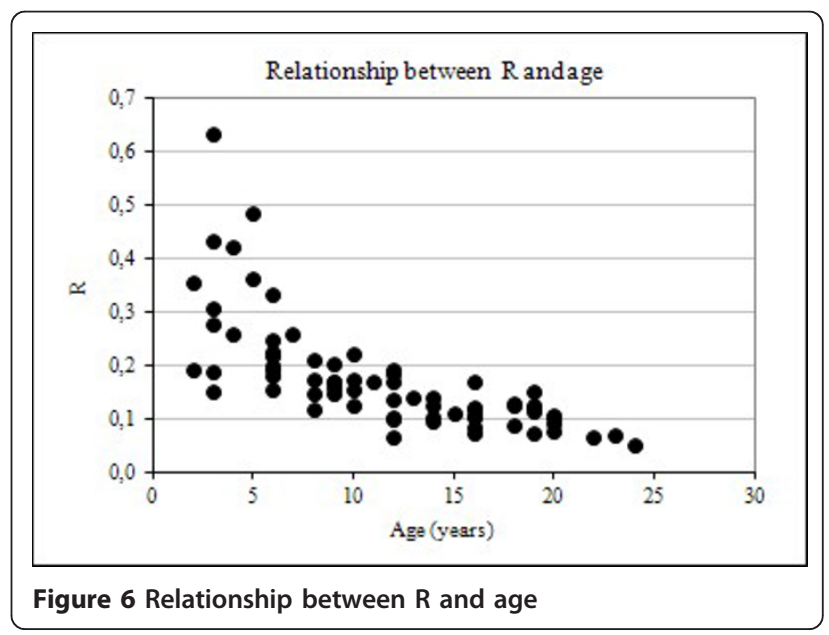


Table 3 Statistics of the fitted models to estimate BEF and $\mathbf{R}$

\begin{tabular}{|c|c|c|c|c|c|c|c|c|}
\hline Model & $\beta_{0}$ & $\beta_{1}$ & $\beta_{2}$ & $\beta_{3}$ & $\beta_{4}$ & $R_{\text {adj }}^{2}$ & $\mathrm{~S}_{\mathrm{yx}}$ & $\mathrm{S}_{\mathrm{yx}} \%$ \\
\hline \multicolumn{9}{|c|}{ MODELS FITTED TO ESTIMATE BEF } \\
\hline 1 & 3.9065 & -0.3522 & - & - & - & 0.72 & 0.25 & $16.92 \%$ \\
\hline 2 & 3.6190 & -0.3697 & - & - & - & 0.75 & 0.23 & $15.98 \%$ \\
\hline 3 & 3.2871 & -0.3684 & - & - & - & 0.75 & 0.23 & $15.96 \%$ \\
\hline 4 & 2.2597 & -0.0392 & - & - & - & 0.53 & 0.32 & $22.10 \%$ \\
\hline 5 & 2.1462 & -0.0446 & - & - & - & 0.52 & 0.33 & $22.45 \%$ \\
\hline 6 & 2.0792 & -0.0532 & - & - & - & 0.44 & 0.35 & $24.20 \%$ \\
\hline 7 & 2.5896 & 0.0301 & & - & - & 0.62 & 0.29 & $20.02 \%$ \\
\hline 8 & 2.3734 & 0.0341 & - & - & - & 0.58 & 0.30 & $20.99 \%$ \\
\hline 9 & 2.3013 & 0.0421 & - & - & - & 0.50 & 0.33 & $22.94 \%$ \\
\hline 10 & 2.2313 & -0.0215 & -0.0347 & 0.0172 & - & 0.53 & 0.32 & $22.21 \%$ \\
\hline 11 & 3.0377 & -0.2048 & - & - & - & 0.70 & 0.26 & $17.89 \%$ \\
\hline 12 & 3.5663 & -0.9055 & 0.0296 & -1.2032 & 0.3844 & 0.78 & 0.22 & $15.60 \%$ \\
\hline \multicolumn{9}{|c|}{ MODELS FITTED TO ESTIMATE R } \\
\hline 1 & 0.5389 & 0.4037 & - & - & - & 0.35 & 0.09 & $48.84 \%$ \\
\hline 2 & 0.5887 & 0.5006 & - & - & - & 0.51 & 0.07 & $42.42 \%$ \\
\hline 3 & 0.5830 & 0.5576 & - & - & - & 0.51 & 0.07 & $42.15 \%$ \\
\hline 4 & 0.4836 & -0.1082 & - & - & - & 0.43 & 0.08 & $45.53 \%$ \\
\hline 5 & 0.4662 & 0.1150 & - & - & - & 0.56 & 0.07 & $39.89 \%$ \\
\hline 6 & 0.4502 & 0.1215 & - & - & - & 0.55 & 0.07 & $40.47 \%$ \\
\hline 7 & 0.4017 & 0.0452 & - & - & - & 0.49 & 0.08 & $43.36 \%$ \\
\hline 8 & 0.3943 & 0.0609 & - & - & - & 0.57 & 0.07 & $39.72 \%$ \\
\hline 9 & 0.4003 & 0.0828 & - & - & - & 0.55 & 0.07 & $40.51 \%$ \\
\hline 10 & 0.3302 & 0.0008 & 0.0077 & 0.0020 & - & 0.53 & 0.07 & $42.14 \%$ \\
\hline 11 & 0.4800 & -0.7298 & - & - & - & 0.53 & 0.07 & $41.45 \%$ \\
\hline 12 & 0.4105 & 0.0901 & -0.1945 & - & - & 0.59 & 0.07 & $39.61 \%$ \\
\hline
\end{tabular}

$24.20 \%$, whereas for $\mathrm{R}$ equations varied from 39.72 to $48.84 \%$. When these two statistics of goodness of fit were taken into consideration, equation 12 was selected as the most accurate, though models 1, 2, 3, and 11 also presented similar performance. Equation 12 was also the most accurate for R estimation, though its mathematical formula differs from the BEF model, because both equations were fitted by means of stepwise regression. A graphical analysis of residuals performed on the 12 equations to estimate BEF and R confirmed those findings (Figures 7 and 8 ).

\section{Comparison of Different Approaches to Estimate Biomass and Carbon Stock}

In order to demonstrate the impact of the various approaches to estimate biomass and carbon stock, an analysis based on the growth and yield simulations from SISPINUS software was performed. This computer program was developed by EMBRAPA - Brazilian Agricultural Research Center and is widely used by the forestry sector in the country and recognized as a reliable tool for simulating growth and yield of pine plantations throughout site conditions.

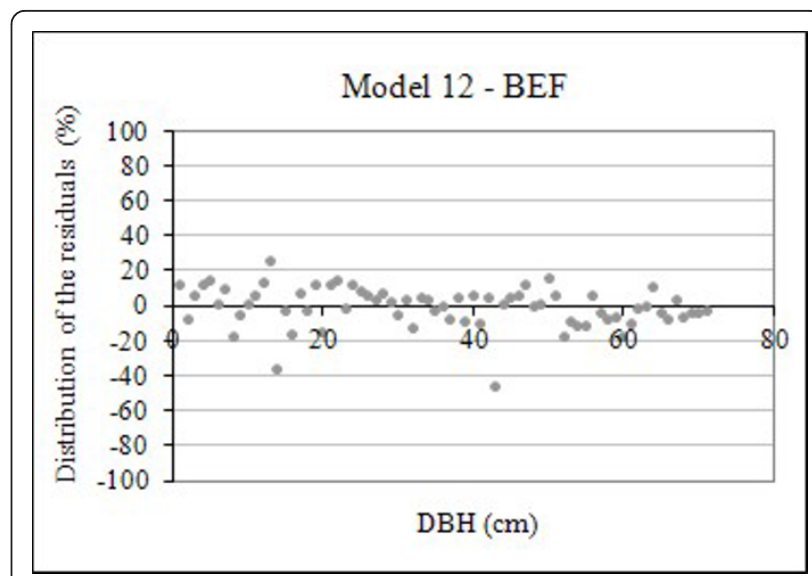

Figure 7 Graphical distribution of the residuals of the fitted models to estimate BEF using equation 12

Growth and yield was simulated for a 1-hectare unthinned 18-year rotation stand, as described before. Based on the predicted volume $\left(511.35 \mathrm{~m}^{3} / \mathrm{ha}\right)$, estimates of total biomass (dry aboveground + belowground biomass), carbon stock and $\mathrm{CO}_{2}$ equivalent were generated by the three different approaches, as described before (Table 4). The estimates using the IPCC [11] default BEF (1.30) and R (0.32) were $334.93 \mathrm{t} / \mathrm{ha}, 137.32$ $\mathrm{tC} / \mathrm{ha}$, and $503.52 \mathrm{tCO}_{2}$ eq./ha, respectively. Using the mean values of $\mathrm{BEF}(1.47)$ and $\mathrm{R}(0.17)$ from the field data the estimates would be $335.69 \mathrm{t} / \mathrm{ha}, 137.63 \mathrm{tC} / \mathrm{ha}$, and $504.66 \mathrm{tCO}_{2}$ eq./ha, respectively for total biomass, carbon stock, and $\mathrm{CO}_{2}$ equivalent. The difference between the estimates for these two approaches was less than $1 \%$. However, when the calculations are made using regression equations the figures change drastically, to $251.32 \mathrm{t}$ of total biomass, $103.04 \mathrm{t} \mathrm{C} / \mathrm{ha}$, and $377.82 \mathrm{t}$ $\mathrm{CO}_{2} \mathrm{eq} / \mathrm{ha}$. Under this condition, the percentage difference in the estimates rises to $33 \%$.

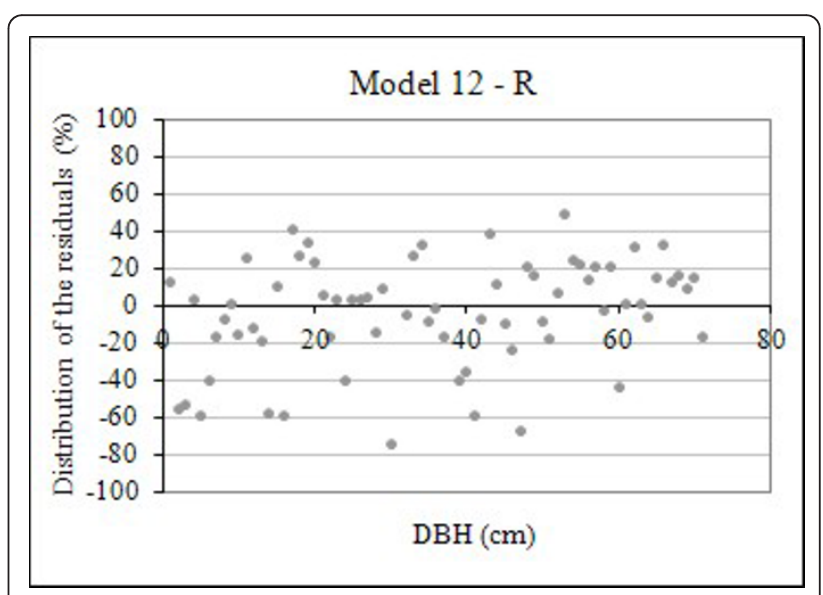

Figure 8 Graphical distribution of the residuals of the fitted models to estimate $R$ using equation 12 
Table 4 Total dry biomass, carbon stock and $\mathrm{CO}_{2}$ equivalent in a one-hectare stand of Pinus spp. using constant IPCC default values for $B E F$ and $R$, mean $B E F$ and $R$ and estimation by regression equations

\begin{tabular}{|c|c|c|c|}
\hline Variable & BEF and R default IPCC $\mathbf{0}$ & Average $\mathrm{BEF}$ and $\mathrm{R} 2$ & $B E F$ and $R$ from regression equations 3 \\
\hline Total biomass (t/ha) & 334.93 & 335.69 & 251.32 \\
\hline Carbon stock (t/ha) & 137.32 & 137.63 & 103.04 \\
\hline $\mathrm{CO}_{2}$ equivalent (t/ha) & 503.52 & 504.66 & 377.82 \\
\hline o-2 & & & \\
\hline Difference (\%) 2 - 3 & & & -33.27 \\
\hline - 3 & & -33.57 & \\
\hline
\end{tabular}

The results shown above indicated that the use of either default or mean BEF and $\mathrm{R}$ values may lead to a gross overestimation in biomass and carbon stocks, and consequently in $\mathrm{CO}_{2}$ removal by sinks in carbon sequestration projects for Pinus species in southern Brazil. Besides the overestimation of the environmental benefits of a project like this, it is also worth mentioning the financial implications of such overestimates. Even in small-scale CDM projects the consequences of such misestimates may be on the order of millions of US dollars. Therefore, project developers should be aware that using simplified methodologies may cause tremendous impacts throughout the offset planning table. Certainly the importance of modeling BEF and $\mathrm{R}$ in a reliable way is crucial for proposing a realistic carbon sequestration project.

\section{Conclusions}

The following conclusions were obtained from the results and discussions of this research:

- For the Pinus elliottii and Pinus taeda plantations analyzed in this study Biomass Expansion Factor (BEF) and Root-to-shoot ratio (R) are strongly correlated with $\mathrm{DBH}$ and total height, and less strongly correlated with tree age. BEF and $\mathrm{R}$ decrease with $\mathrm{DBH}$, height and tree age. The relationship between them suggests a negative exponential curve toward an asymptote with increasing BEF and R.

- In this study the highest $\mathrm{R}^{2}$ and lowest Syx could be achieved using a combination of the following independent variables: $\mathrm{DBH}$, height and age for BEF estimation; and DBH and height for $\mathrm{R}$ estimation; - The use of default BEF and R should be avoided due to the great possibility of obtaining spurious results. For pine plantations in southern Brazil the overestimation may be over 33\%;

- Finally, caution should be used by forest offset developers since the process of verification and certification may not confirm $\mathrm{CO}_{2}$ removals from sinks predicted by a project that uses either default or mean $\mathrm{BEF}$ and $\mathrm{R}$ values.

\section{Methods}

\section{Field Data}

The data used in this study came from 70 sampled Pinus elliottii and P. taeda individuals growing across southern Paraná State, Brazil. A direct method (weighing) was applied to obtain fresh biomass weight in the field. Belowground biomass was obtained after excavation and cleaning of the roots over $2 \mathrm{~mm}$ of diameter at $50 \mathrm{~cm}$ depth.

The sampled trees were representative of the local conditions and previously categorized by $\mathrm{DBH}$ and age classes. Girth at breast height of each sample tree was measured using ordinary metric tape, and values were converted to $\mathrm{DBH}$ for calculations and modeling. After felling, the top bole length of each tree was measured using tape and taken to be tree total height - H. Age was determined by tree ring counting and from historic records.

For the biomass weighing in the field, each tree was cut up into five biomass pools: bole, thick branches over $4 \mathrm{~cm}$ of diameter, thin branches under $4 \mathrm{~cm}$ of diameter, foliage, and roots. Biomass was determined following IPCC recommendations [11]. Each biomass pool was weighed using a mechanical balance with a $100 \mathrm{~kg}$ capacity and $100 \mathrm{~g}$ precision. A $500 \mathrm{~g}$ sample was taken from each biomass pool to determine dry weight, percentage of dry matter and carbon fraction in the laboratory. Carbon fraction was determined using a LECO-144 combustion chamber.

\section{Calculation of BEF and $\mathbf{R}$}

The biomass expansion factor (BEF) definition used in this study is based upon FAO (1997) [36], i.e., the ratio of aboveground oven-dry biomass of trees to oven-dry biomass of inventoried volume. Since for the conditions of this study the inventoried volume is the total bole, BEF becomes as shown by the following ratio:

$$
\mathrm{BEF}=\frac{\mathrm{W}_{\text {crown }}+\mathrm{W}_{\text {bole }}}{\mathrm{W}_{\text {bole }}}=\frac{\mathrm{W}_{\text {aboveground }}}{\mathrm{W}_{\text {bole }}}
$$

where: 


\begin{tabular}{llll}
\hline MODELS FITTED TO BEF & \multicolumn{2}{l}{ MODELS FITTED TO R } \\
\hline 1 & $B E F=\beta_{0} * D B H^{-\beta_{1}}$ & 1 & $R=\beta_{0} * D B H^{-\beta_{1}}$ \\
2 & $B E F=\beta_{0} * H^{-\beta_{1}}$ & 2 & $R=\beta_{0} * H^{-\beta_{1}}$ \\
3 & $B E F=\beta_{0} * A G E^{-\beta_{1}}$ & 3 & $R=\beta_{0} * A G E^{-\beta_{1}}$ \\
4 & $B E F=\beta_{0}+\beta_{1}^{*} \operatorname{Ln}(D B H)$ & 4 & $R=\beta_{0}+\beta_{1}^{*} \operatorname{Ln}(D B H)$ \\
5 & $B E F=\beta_{0}+\beta_{1}^{*} \operatorname{Ln}(H)$ & 5 & $R=\beta_{0}+\beta_{1}^{*} \operatorname{Ln}(H)$ \\
6 & $B E F=\beta_{0}+\beta_{1}^{*} \operatorname{Ln}(A G E)$ & 6 & $R=\beta_{0}+\beta_{1}^{*} \operatorname{Ln}(A G E)$ \\
7 & $B E F=\beta_{0} * E X P^{\left(-\beta_{1} * D B H\right)}$ & 7 & $R=\beta_{0} * E X P^{\left(-\beta_{1} * D B H\right)}$ \\
8 & $B E F=\beta_{0} * E X P^{\left(-\beta_{1} * H\right)}$ & 8 & $R=\beta_{0} * E X P^{\left(-\beta_{1} * H\right)}$ \\
9 & $B E F=\beta_{0} * E X P^{\left(-\beta_{1} * A G E\right)}$ & 9 & $R=\beta_{0} * E X P^{\left(-\beta_{1} * A G E\right)}$ \\
10 & $B E F=\beta_{0}+\beta_{1}^{*} D B H+\beta_{2}^{*} H+\beta_{3}^{*} A G E$ & 10 & $R=\beta_{0}+\beta_{1}^{*} D B H+\beta_{2}^{*} H+\beta_{3}^{*} A G E$ \\
11 & $B E F=\beta_{0}+\beta_{1}^{*} \ln \left(D B H^{*} H^{*} A G E\right)$ & 11 & $R=\beta_{0}+\beta_{1}^{*} \ln \left(D B H * H^{*} A G E\right)$ \\
12 & $B E F=\beta_{0}+\beta_{1}^{*} \operatorname{In} D B H+\beta_{2}^{*} D B H+\beta_{3}^{*} \operatorname{In} H+\beta_{4}^{*} \operatorname{In}\left(D B H * H^{*} A G E\right)$ & 12 & $R=\beta_{0}+\beta_{1}^{*} \ln D B H+\beta_{2}^{*} \ln H$ \\
\hline
\end{tabular}

where: $\beta_{\mathrm{i}}=$ coefficients.

$B E F=$ biomass expansion factor (dimensionless);

$W_{\text {crown }}=$ tree crown dry weight $(\mathrm{g})$, composed of foliage, thick and thin branches;

$W_{\text {bole }}=$ tree bole dry weight $(\mathrm{g})$; and

$W_{\text {aboveround }}=W_{\text {crown }}+W_{\text {bole }}(\mathrm{g})$.

The root-to-shoot ratio calculations were conducted using the formula below, as indicated by the [11], which defines $\mathrm{R}$ as the ratio of belowground (root) to aboveground biomass (shoot), as follows:

$$
\mathrm{R}=\frac{\mathrm{W}_{\text {root }}}{\mathrm{W}_{\text {aboveground }}}
$$

where:

$R$ = root-to-shoot ratio (dimensionless); and

$W_{\text {root }}=$ tree root dry weight $(\mathrm{g})$.

\section{Statistical Analysis and Mathematical Modelling}

Correlation coefficients of all variable combinations were calculated in order to understand the relationships among them and in turn to develop models to estimate $\mathrm{BEF}$ and $\mathrm{R}$ as functions of the more easily measured forest inventory variables ( $\mathrm{DBH}, \mathrm{H}$, and Age). Twelve mathematical models were tested to estimate $\mathrm{BEF}$ and $\mathrm{R}$ from $\mathrm{DBH}$, tree height and age as and presented in Table 5. Only linear models were chosen by the criteria of simplicity and easy-to-fit.

The best-fit model was selected in accordance with the following criteria: smallest percentage standard error of estimate $\left(\right.$ Syx $\left._{\%}\right)$, highest coefficient of determination adjusted to number of cases and coefficients $\left(R^{2}\right.$ adj $)$, and optimal performance in a graphical analysis of residuals.

\section{Comparison of Different Approaches to Estimate Biomass and Carbon Stocks}

A comparison of three approaches to calculate BEF and $\mathrm{R}$ was performed. The first approach consisted of using constant IPCC values for pine plantations in the tropics,
$\mathrm{BEF}=1.30$ and $\mathrm{R}=0.32$ [11], whereas the second took into account fixed values calculated from the average BEF and $\mathrm{R}$ of the trees sampled in this study. The third approach used size- and age-dependent estimates of $\mathrm{BEF}$ and $\mathrm{R}$ derived from the best-fit equation selected from the 12 models tested in this study.

The comparison was done by calculating $\mathrm{CO}_{2}$ equivalent from the three approaches, using volume estimation from a growth and yield simulator called SISPINUS [37]. Carbon dioxide equivalent was used for comparison because it is the variable used in carbon sequestration projects. The input variables for SISPINUS were: number of trees per hectare $=1,667$; site index $=23 \mathrm{~m}$ (dominant tree height) at age 15 years; and rotation age $=18$ years for an unthinned hypothetical stand. The output variable (total bole volume) was converted to carbon stock $(\mathrm{t} / \mathrm{ha})$ by multiplying wood density $(0.3817$ g. $\mathrm{cm}^{-3}$ according to Sette JR et al. (2006) [38] to 0.41 carbon fraction of dry matter (tC.d.m. $)^{-1}$, from lab determination, in accordance with IPCC nomenclature [11]. Carbon stock was in turn converted to $\mathrm{CO}_{2}$ equivalent ( $\mathrm{t} / \mathrm{ha})$ by multiplying by the ratio $44 / 12(1$ mole $\mathrm{C}=12$, 1 mole $\mathrm{O}=12$, therefore 1 mole $\mathrm{CO}_{2}=44$ ).

\section{Acknowledgements}

We would like to thank Conselho Nacional de Desenvolvimento Científico e Tecnológico (CNPq) of Brazil for financial support.

\section{Author details}

'Department of Forest Science, Federal University of Paraná, Curitiba, PR, Brazil. Av. Prof. Lothário Meissner, 900, Jardim Botânico, Curitiba, Paraná, 80.210-170, Brazil. 'Forestry Research Foundation of Paraná, Curitiba, PR, Brazil. Av. Prof. Lothário Meissner, 900, Jardim Botânico, Curitiba, Paraná, 80.210-170, Brazil. ${ }^{3}$ Course student at National Research Institute of Amazonia, Manaus, AM, Brazil. Av. Prof. Lothário Meissner, 900, Jardim Botânico, Curitiba, Paraná, 80.210-170, Brazil.

\section{Authors' contributions}

CRS, APDC and FS conceived, drafted the manuscript and developed the methodological approaches. All authors read and approved the final manuscript. 


\section{Competing interests}

The authors declare that they have no competing interests. The views expressed in this publication are those of the authors.

Received: 9 November 2010 Accepted: 24 September 2011 Published: 24 September 2011

\section{References}

1. Somogyi Z, Cienciala E, Makipaa R, Muukkonen P, Lehtonen A, Weiss P: Indirect methods of large-scale forest biomass estimation. European Journal of Forest Research 2006, 126(2):197-207.

2. Sanquetta CR, Corte APD, Balbinot R, Zilliotto MAB: Proposta metodológica para quantificação e monitoramento do carbono estocado em florestas plantadas. In Mercado de carbono: mercado e ciência. Volume 1. Edited by: Carlos Roberto Sanquetta, Marco Aurélio Zilliotto. Curitiba: UFPR; 2006:120-150

3. Johnson WC, Sharpe DM: The ratio of total to merchantable forest biomass and its application to the global carbon budget. Can J For Res 1983, 13:372-383.

4. Karjalainen T, Kellomäki S: Greenhouse gas inventory for land use changes and forestry in Finland based on international guidelines. Mitigation Adapt Strategies Global Climate 1996, n. 1:51-71.

5. Weiss P, Schieler K, Schadauer K, Radunsky k, Englisch M: Die Kohlenstoffbilanz des österreichischen Waldes und Betrachtungen zum Kyoto-Protokoll. Series Die Kohlenstoffbilanz des österreichischen Waldes und Betrachtungen zum Kyoto-Protokoll Federal Environment Agency, Wien; 2000.

6. Kauppi PE, Mielikäinen K, Kuusela K: Biomass and carbon budget of European forests, 1971-1990. Science 1992, 256:70-74.

7. Kauppi $P E$, Kauppi $E$, Tomppo E, Ferm A: $C$ and $\mathrm{N}$ storage in living trees within Finland since 1950s. Plant Soil 1995, 168/169:633-638.

8. Löwe $H$, Seufert $G$, Raes F: Comparison of methods used within member states for estimating $\mathrm{CO}_{2}$ emissions and sinks according to UNFCCC and EU monitoring mechanism: forest and other wooded land. Biotechnol Agron Soc Environ 2000, 4:315-319.

9. UN-ECE/FAO: Forest Resources of Europe, CIS, North America, Australia, Japan and New Zealand (industrialized temperate/boreal countries). UNECE/FAO Contribution to the Global Forest Resources Assessment 2000 Main Report United Nations, New York, Geneva; 2000, 2000 UN-ECE/FAO.

10. FAO: Global Forest Resource Assessment 2000 FAO Forestry Paper 140. FAO, Rome; 2001

11. IPCC: plntergovernmental Panel on Climate Change. Guidelines for National Greenhouse Gas Inventories 2006 [http://www.ipcc.ch].

12. Satoo T, Madgwick HAl: Forest biomass. Forestry Sciences Martinus Nijhoff/ Dr. W. Junk Publisher, The Hague; 1982, 152

13. Bartelink HH: Allometric relationships for biomass and leaf area of beech (Fagus sylvatica L.). Ann For Sci 1997, 54:39-50.

14. Ter-Mikaelian MT, Korzukhin MD: Biomass equations for sixty-five North American tree species. For Ecol Manage 1997, 97:1-24.

15. Lehtonen A, Mäkipää R, Heikkinen J, Sievänen R, Liski J: Biomass expansion factors (BEFs) for Scots pine, Norway spruce and birch according to stand age for boreal forests. Forest Ecology and Management 2004, 188(1 (3)):211-224

16. Levy PE, Hale SE, Nicoli BC: Biomass expansion factors and root: shoot ratios for coniferous tree species in Great Britain. Forestry 2010, 77(5):421-430.

17. Liski J, Perruchoud D, Karjalainen T: Increasing carbon stocks in the forest soils of Western Europe. For Ecol Manage 2002, 169:163-179.

18. Schroeder P, Brown S, Mo J, Birdsey R, Cieszewski C: Biomass estimation for temperate broadleaf forests of the United States using inventory data. For Sci 1997, 43:424-434.

19. Brown SL, Schroeder PE: Spatial patterns of aboveground production and mortality of woody biomass for Eastern US forests. Ecol Applicat 1999, 9:968-980

20. Brown S: Measuring carbon in forests: current status and future challenges. Environ Pollut 2002, 116:363-372.

21. Fukuda M, lehara T, Matsumoto M: Carbon stock estimates for sugi and hinoki forests in Japan. For Ecol Manage 2003, 184:1-16.

22. Ishii $\mathrm{H}, \mathrm{Mcd}$ owell NG: The role of epicormic branches in crown development of old Douglas-fir trees. Forest Ecology and Management 2002, 3(169):257-270
23. Binkley D, Stape JL, Ryan MG, Barnard H, Fownes J: Age-related decline in forest ecosystem growth: an individual-tree, stand-structure hypothesis. Ecosystems 2002, 5:58-67.

24. Vanninen $P$, Ylitalo $H$, Sievanen $R$, Makela A: Effects of age and site quality on the distribution of biomass in Scots pine (Pinus sylvestris L.). Trees Structure and function 1996, 10(4):231-238.

25. Mäkelä AA: Carbon balance model of growth and self-pruning in trees based on structural relationships. Forest Science 1997, 1(43):7-24.

26. Li MH, Krauchi N, Dobbertin M: Biomass distribution of different-aged needles in young and old Pinus cembra trees at highland and lowland sites. Trees - Structure and function 2006, 10(5):611-618.

27. Nutto L, Spathelf P: Modelagem da desrama natural de Araucaria angustifolia (BERT.) O. KTZE. Revista Floresta 2003, 3(33):295-309.

28. Ruel J, Aires M: Jensen's inequality predicts effects of environmental variation. Tree 1999, 14(9).

29. Rastetter EB, Mckane RB, Shaver GR, Melillo JM: Changes in C storage by terrestrial ecosystems: how $\mathrm{C}-\mathrm{N}$ interactions restrict responses to $\mathrm{CO} 2$ and temperature. Water, Air and Soil Pollution 1992, 64: 327-344.

30. Magnani F, Mencuccini M, Grace J: Age-related decline in stand productivity: the role of structural acclimation under hydraulic constraints. Plant Cell Environ 2000, 23:251-263.

31. Kira T, Shidei R: Primary production and turnover of organic matter in different forest ecosystems of the western Pacific. Japanese Journal of Ecology 1967, 17(1):70-87.

32. Barnes BV, Zak DR, Denton SR, Spurr SH: Forest Ecology. Wiley, New York; 4 1998, 792.

33. Ryan MG, Binkley D, Fownes $J H$, Giardina CP, Senock RS: An experimental test of the causes of forest growth decline with stand age. Ecological Monographs 2004, 74(3):393-414.

34. Ryan M, Phillips N, Bond BJ: The hydraulic limitation hypothesis revisited. Plant, Cell and Environment 2006, 29:367-381.

35. Soares $\mathrm{P}$, Tomé $\mathrm{M}$ : Analysis of the effectiveness of biomass expansion factors to estimate stand biomass. In Modeling Forest Production. Edited by: Hasenauer H, Makela A. Proc. Conf. Vienna, 19-21 April (Department of Forest and Soil Sciences, BOKU University of Natural Resources and Applied Life Sciences, Vienna; 2004:368-374.

36. FAO: State of the world's forests 1997 Food and Agricultural Organization of the United Nations; 1997, 200.

37. Oliveira EB: Um sistema computadorizado de prognose do crescimento e produção de Pinus taeda L., com critérios quantitativos para avaliação técnica e econômica de regimes de manejo (Tese - Doutorado em Ciências Florestais) - Setor de Ciências Agrárias, Universidade Federal do Paraná, Curitiba; 1995, 134

38. Sette JRCR, Nakajima NY, Geromini MP: Captura de carbono orgânico em povoamentos de Pinus taeda L. na região de Rio Negrinho, SC. In Revista Floresta. Volume 36. Curitiba; 2006:(1):33-44.

doi:10.1186/1750-0680-6-6

Cite this article as: Sanquetta et al.: Biomass expansion factor and rootto-shoot ratio for Pinus in Brazil. Carbon Balance and Management 2011 6:6.

\section{Submit your next manuscript to BioMed Central and take full advantage of:}

- Convenient online submission

- Thorough peer review

- No space constraints or color figure charges

- Immediate publication on acceptance

- Inclusion in PubMed, CAS, Scopus and Google Scholar

- Research which is freely available for redistribution 